\title{
IMPLIKASI PEMBERLAKUAN UNDANG-UNDANG OTORITAS JASA KEUANGAN TERHADAP PERLINDUNGAN KONSUMEN JASA KEUANGAN DIKAITKAN UNDANG-UNDANG PERLINDUNGAN KONSUMEN
}

\author{
Agus Suwandono \\ Departemen Hukum Ekonomi, Fakultas Hukum Universitas Padjadjaran \\ e-mail: agus.suwandono@unpad.ac.id
}

\begin{abstract}
ABSTRAK
Pemberlakuan Undang-Undang No. 21 Tahun 2011 tentang Otoritas Jasa Keuangan (UUOJK), membawa harapan dan kepastian hukum bagi perlindungan konsumen di sektor jasa keuangan di Indonesia. Namun demikian sebelum pemberlakuan UUOJK, telah terdapat pengaturan mengenai perlindungan konsumen, yakni dalam Undang-Undang No. 8 Tahun 1999 tentang Perlindungan Konsumen (UUPK). Ruang lingkup pengaturan UUPK pada dasarnya juga mencakup perlindungan konsumen di sektor jasa keuangan yakni perbankan, lembaga pembiayaan dan asuransi. Metode penelitian merupakan metode yuridis normatif yakni penelitian hukum yang dilakukan dengan cara meneliti bahan pustaka atau data sekunder. Penelitian bersifat deskriptif analitis dengan menggunakan metode normatif. Berdasarkan hasil dan pembahasan diperoleh kesimpulan bahwa pengaturan perlindungan konsumen di sektor jasa keuangan dalam UUOJK pada dasarnya merupakan peraturan khusus yang mengatur mengenai perlindungan konsumen di sektor jasa keuangan. Namun karena adanya perbedaan definisi konsumen dalam UUPK dan UUOJK maka secara umum UUPK bukan merupakan lex generalis dari UUOJK. UUOJK dapat dipandang sebagai lex specialis dari UUPK sepanjang mengenai konsumen dalam pengertian konsumen menurut UUPK.
\end{abstract}

Kata Kunci: implikasi, jasa keuangan, konsumen, UUOJK, UUPK.

\section{ABSTRACT}

Enforcement of the Act No. 21 Year 2011 on the Financial Services Authority (UUOJK) brings hope and legal certainty for consumer protection in the financial service sector in Indonesia. However, there has been a regulation on consumer protection, namely in Law No. 8 of 1999 on Consumer Protection (UUPK) before the enactment of UUOJK. The scope of UUPK regulation also basically includes consumer protection in the financial service sector which are banking, finance and insurance institutions. This study is a normative legal research which studies library materials or secondary data. The study is analytical descriptive that uses normative methods. Based on the results and discussion, it is concluded that regulation of consumer protection in the financial service sector written in UUOJK is basically special rules governing consumer protection in the financial service sector. However, UUPK is generally not a lex generalis of UUOJK due to different definition of consumer in UUPK and UUOJK. In the case of term consumer according to UUPK, UUOJK can be regarded as lex specialis of UUPK.

Keywords: implications, financial service, consumer, UUOJK, UUPK.

\section{PENDAHULUAN}

Undang-Undang No. 21 Tahun 2011 tentang Otoritas Jasa Keuangan (yang selanjutnya disebut UUOJK) merupakan ketentuan baru yang mengatur pelaksanaan kegiatan sektor jasa keuangan di Indonesia. Pemberlakuan UUOJK telah membawa harapan dan kepastian hukum terhadap pelaksanaan kegiatan di sektor jasa keuangan yakni dengan pembentukan suatu lembaga Otoritas Jasa Keuangan (yang selanjutnya disebut OJK). OJK merupakan lembaga independen dan bebas dari campur tangan 
pihak lain, yang mempunyai fungsi, tugas dan wewenang pengaturan, pengawasan, pemeriksaan dan penyidikan kegiatan di sektor jasa keuangan. ${ }^{1}$

Salah satu tujuan pembentukan OJK adalah untuk melindungi kepentingan konsumen dan masyarakat ${ }^{2}$ yang menggunakan atau memanfaatkan pelayanan lembaga jasa keuangan. OJK dalam rangka melindungi kepentingan konsumen dan masyarakat, diberikan kewenangan untuk melakukan edukasi, pelayanan pengaduan, sampai dengan pembelaan hukum terhadap konsumen yang dirugikan oleh lembaga jasa keuangan. OJK dalam menjalankan kewenangannya melindungi kepentiangan konsumen dan masyarakat dapat memfasilitasi penyelesaian pengaduan konsumen yang dirugikan oleh pelaku usaha lembaga jasa keuangan. ${ }^{3}$ Pembelaan hukum terhadap konsumen oleh OJK dapat berupa memerintahkan atau melakukan tindakan tertentu kepada lembaga jasa keuangan dan mengajukan gugatan untuk memperoleh kembali harta kekayaan konsumen atau memperoleh ganti rugi untuk konsumen. ${ }^{4}$

Sebelum pemberlakuan UUOJK, pengaturan perlindungan konsumen di Indonesia telah diatur secara khusus dalam Undang-Undang No. 8 Tahun 1999 tentang Perlindungan Konsumen (yang selanjutnya disebut UUPK). UUPK merupakan umbrella act dalam perlindungan konsumen di Indonesia. ${ }^{5}$ Ruang lingkup pengaturan UUPK pada dasarnya mencakup perlindungan konsumen terhadap pengunaan barang dan/atau jasa. Perlindungan hukum yang diberikan oleh UUPK terhadap barang dan/ atau jasa secara umum yakni perlindungan terhadap penggunaan barang dan jasa. Pada dasarnya konsumen jasa di sektor jasa keuangan pun dapat dilindungi oleh UUPK manakala dirugikan oleh pelaku usaha sektor jasa keuangan. Konsumen jasa di sektor jasa keuangan antara lain konsumen di sektor perbankan, pembiayaan $^{6}$ dan asuransi.

\footnotetext{
${ }^{1}$ Pasal 1 angka (1) Undang-Undang No. 21 Tahun 2011 tentang Otoritas Jasa Keuangan (UUOJK).

${ }^{2}$ Pasal 4 huruf (c) UUOJK.

${ }^{3}$ Pasal 29 huruf (c) UUOJK.

${ }^{4}$ Pasal 30 UUOJK.

${ }^{5}$ Agus Satory, "Perjanjian Baku dan Perlindungan Konsumen dalam Transaksi Bisnis Sektor Jasa Keuangan: Penerapan dan Implementasinya di Indonesia", Padjadjaran Jurnal Ilmu Hukum, Vol. 2 No. 2, Agustus 2015, h. 272.

${ }^{6}$ Ibid., h. 273.
}

Pemberlakuan UUOJK di satu sisi dapat memberikan perlindungan hukum bagi konsumen di sektor jasa keuangan, namun di satu sisi juga menimbulkan ketidakjelasan pengaturannya. Hal ini mengingat bahwa selama ini payung hukum pelaksanaan perlindungan hukum terhadap konsumen di Indonesia adalah UUPK. Apakah dalam hal ini UUOJK merupakan suatu ketentuan lex specialis dari UUPK, sehingga ketentuan-ketentuan dalam UUPK dapat diberlakukan sebagai ketentuan lex generalis. Ataukah memang ke-2 (dua) undangundang ini memang mengatur materi yang berbeda, sehingga asas lex specialis derogat legi generali tidak bisa diterapkan, yang artinya bahwa ketentuanketentuan dalam UUPK tidak dapat digunakan untuk melindungi konsumen di sektor jasa keuangan. Hal ini mengingat bahwa adanya perbedaan pengertian konsumen dalam UUPK dan UUOJK. UUPK hanya melindungi konsumen dalam pengertian sebagai konsumen akhir yakni pengguna terakhir atau pemanfaat akhir suatu produk atau end user. $^{7}$ Konsumen sebagai pengguna akhir atau end user di mana tidak ada motif untuk memperoleh keuntungan dari transaksi yang dilakukan konsumen dengan pelaku usaha. ${ }^{8}$ Hal ini berbeda dengan pengertian konsumen dalam UUOJK yakni konsumen adalah pihak-pihak yang menempatkan dananya dan/atau memanfaatkan pelayanan yang tersedia di Lembaga Jasa Keuangan. ${ }^{9}$ Konsumen di sektor jasa keuangan dapat berkedudukan sebagai pelaku usaha.

Perbedaan pengertian konsumen dalam UUPK dan UUOJK, menyebabkan perbedaan penafsiran apakah setiap konsumen jasa keuangan dapat dikatakan sebagai konsumen menurut UUPK. Sehingga jika konsumen di sektor jasa keuangan dapat dikategorikan sebagai konsumen menurut UUPK, seperti sebelum pemberlakuan UUOJK di mana konsumen di sektor jasa keuangan (perbankan, pembiayaan dan asuransi) juga dapat menggunakan UUPK sebagai dasar perlindungan hukum terhadap konsumen. Sementara itu UUPK sendiri hanya memberikan perlindungan hukum terhadap konsumen

\footnotetext{
${ }^{7}$ Ahmadi Miru \& Sutarman Yado, Hukum Perlindungan Konsumen, RajaGrafindo Persada, Jakarta, 2007, h. 7.

8 Nurul Fibrianti, "Perlindungan Konsumen dalam Penyelesaian Sengketa Konsumen melalui Jalur Litigasi”, Jurnal Hukum Acara Perdata ADHAPER, Vol. 1 No. 1, Januari-Juni 2015, h. 122.

${ }^{9}$ Pasal 1 angka (15) UUOJK.
} 
akhir, ${ }^{10}$ yakni konsumen pemakai barang dan atau jasa dan tidak untuk diperdagangkan.

Selanjutnya UUOJK juga telah menentukan ketentuan-ketentuan untuk melindungi konsumen dan masyarakat di sektor jasa keuangan sebagaimana diatur dalam Pasal 28-31 UUOJK. OJK diberikan kewenangan untuk memfasilitasi penyelesaian sengketa antara konsumen dengan lembaga jasa keuangan dan memiliki kewenangan untuk melakukan pembelaan hukum antara lain melakukan gugatan kepada lembaga jasa keuangan/atau pihak lain yang merugikan konsumen.

OJK dalam melindungi kepentingan konsumen dan masyarakat juga telah menerbitkan Peraturan Otoritas Jasa Keuangan No. 1/POJK.07/2013 tentang Perlindungan Konsumen Sektor Jasa Keuangan (POJK Perlindungan Konsumen) dan Peraturan Otoritas Jasa Keuangan No. 1/POJK.07/2014 tentang Lembaga Alternatif Penyelesaian Sengketa (LAPS) Sektor Jasa Keuangan (POJK LAPS). Kedua POJK di atas telah menentukan bahwa penyelesaian sengketa konsumen dapat diselesaikan melalui pengadilan atau pun di luar pengadilan yakni melalui Lembaga Alternatif Penyelesaian Sengketa (LAPS) di sektor jasa keuangan.

Sebelum dimulai pemberlakuan UUOJK, POJK Perlindungan Konsumen dan POJK LAPS sebenarnya UUPK juga telah memberikan perlindungan konsumen dalam penyelesaian sengketa konsumen. UUPK telah memberikan kemudahan-kemudahan bagi konsumen dalam rangka perlindungan terhadap konsumen, antara lain berkaitan tempat pengajuan gugatan di tempat kedudukan konsumen, pembalikan beban pembuktian (unsur kesalahan), serta pengakuan adanya gugatan perwakilan kelompok atau class action. Selain itu, UUPK juga telah menentukan lembaga yang bertugas menyelesaikan sengketa konsumen dan pelaku usaha di luar pengadilan yakni dilaksanakan oleh Badan Penyelesaian Sengketa Konsumen (yang selanjutnya disebut BPSK) dengan segala kemudahan yang telah atur oleh UUPK. Apakah dengan pemberlakuan UUOJK, konsumen jasa di sektor jasa keuangan tetap dapat menggunakan UUPK, ataukah harus sesuai dengan ketentuan yang diatur dalam UUOJK, atau dapat digunakan secara bersamaan dalam rangka melindungi kepentingan hukum konsumen.

\footnotetext{
${ }^{10}$ Penjelasan Pasal 1 angka (2) UUPK.
}

\section{PERUMUSAN MASALAH}

Berdasarkan uraian di atas dengan menggunakan metode pendekatan perundang-undangan, maka dirumuskan permasalahan sebagai berikut yakni, Bagaimanakah pengaturan perlindungan hukum terhadap konsumen jasa keuangan pasca pemberlakuan UUOJK dikaitkan dengan UUPK, serta Bagaimanakah perlindungan hukum terhadap konsumen jasa keuangan pasca pemberlakuan UUOJK dikaitkan dengan UUPK.

Adapun tujuan tulisan ini adalah untuk mengetahui dan menganalisis implikasi pemberlakuan UUOJK terhadap perlindungan konsumen jasa keuangan.

\section{PEMBAHASAN}

\section{Pengaturan Perlindungan Hukum terhadap Konsumen Jasa Keuangan Pasca Pemberlakuan UUOJK Dikaitkan dengan UUPK}

Pengaturan perlindungan hukum terhadap konsumen di Indonesia telah diatur secara khusus dalam UUPK. Walaupun sudah diatur secara khusus dalam UUPK, pada dasarnya UUPK bukanlah merupakan awal atau akhir dari hukum yang mengatur mengenai perlindungan konsumen, sebab sampai pada terbentuknya UUPK telah terdapat beberapa ketentuan perundang-undangan yang materinya juga melindungi konsumen. ${ }^{11}$ UUPK juga masih membuka kemungkinan dikemudian hari untuk terbentuknya undang-undang baru yang pada dasarnya memuat ketentuan-ketentuan yang melindungi konsumen. Sehingga dalam hal ini kedudukan UUPK merupakan payung yang mengintegrasikan dan memperkuat penegakan hukum di bidang perlindungan konsumen. ${ }^{12}$

UUPK sebagai peraturan khusus yang bertujuan untuk mengatur dan melindungi konsumen dapat dikatakan sebagai ketentuan khusus atau lex specialis bagi undang-undang yang telah ada, yang juga melindungi kepentingan konsumen, antara lain yang diatur dalam Kitab Undang-Undang Hukum Perdata (KUHPerdata). Namun, di sisi yang lain UUPK juga dapat berlaku sebagai undang-undang yang sifatnya umum atau lex generalis terhadap suatu ketentuan undang-undang yang mengatur perlindungan konsumen yang lebih khusus, misalnya perlindungan konsumen di sektor jasa keuangan. Maka dalam hal ini ketentuan-ketentuan UUPK pada dasarnya dapat diberlakukan terhadap perlindungan konsumen yang

\footnotetext{
11 Penjelasan Umum UUPK.

12 Penjelasan Umum UUPK.
} 
sifatnya lebih khusus, kecuali apabila ditentukan lain dalam undang-undang yang sifatnya khusus tersebut.

UUOJK merupakan undang-undang yang di dalamnya juga mengatur mengenai perlindungan konsumen, khususnya perlindungan konsumen di sektor jasa keuangan. Selain itu UUOJK juga telah mengamanatkan pembentukan suatu lembaga OJK yang berwenang untuk melakukan pengaturan, pengawasan, pemeriksaan dan penyidikan di sektor jasa keuangan. Pemberlakuan UUOJK dan pembentukan OJK bertujuan untuk terselenggaranya kegiatan di sektor jasa keuangan yang teratur, adil, transparan, dan akuntabel, serta mewujudkan sistem keuangan yang tumbuh secara berkelanjutan dan mampu melindungi kepentingan konsumen sektor jasa keuangan. ${ }^{13}$ Pembentukan OJK dimaksudkan agar pengawasan lebih terintegrasi dan koordinasinya lebih mudah sehingga pengawasan dan regulasinya menjadi efektif. ${ }^{14}$

Pengaturan perlindungan hukum terhadap konsumen dalam UUPK pada dasarnya memberikan perlindungan secara luas yakni perlindungan hukum terhadap konsumen barang dan/atau jasa. Adapun pengaturan perlindungan konsumen dalam UUOJK merupakan perlindungan hukum terhadap konsumen yang lebih khusus yakni konsumen di bidang jasa, yakni di sektor jasa keuangan.

Pasal 1 angka (2) UUPK menegaskan bahwa, Konsumen adalah setiap orang pemakai barang dan jasa yang tersedia dalam masyarakat, baik bagi kepentingan diri sendiri, keluarga, orang lain, maupun makhluk hidup lain dan tidak untuk diperdagangkan. Pengertian konsumen dalam UUPK adalah setiap orang pemakai barang dan jasa sebagai konsumen akhir, yakni pengguna atau pemanfaat akhir dari suatu produk. Sehingga UUPK hanya melindungi konsumen dalam pengertian konsumen akhir, sedangkan konsumen antara/pelaku perdagangan/ pelaku usaha berdasarkan ketentuan UUPK tidak dapat mendapatkan perlindungan, karena bukan sebagai konsumen akhir. Pasal 1 angka (15) UUOJK menegaskan bahwa, Konsumen adalah pihak-pihak yang menempatkan dananya dan/atau memanfaatkan pelayanan yang tersedia di Lembaga Jasa Keuangan antara lain nasabah pada perbankan, pemodal di pasar modal, pemegang polis pada perasuransian,

\footnotetext{
${ }^{13}$ Konsiderans UUPK.

${ }^{14}$ Adrian Sutedi, Aspek Hukum Otoritas Jasa Keuangan, Raih Asa Sukses, Jakarta, 2014, h. 39.
}

dan peserta pada dana pensiun, berdasarkan peraturan perundang-undangan di sektor jasa keuangan.

Pengertian konsumen dalam UUOJK merupakan konsumen yang secara khusus di sektor jasa keuangan, yakni pihak-pihak yang menempatkan dananya dan/atau memanfaatkan pelayanan yang tersedia di lembaga jasa keuangan. Pihak yang menempatkan dana dapat berupa perseorangan maupun badan usaha baik yang berbadan hukum maupun tidak berbadan hukum. Dalam pengertian ini, konsumen menurut UUOJK juga dapat berasal dari pelaku usaha.

Jika melihat dari kedua pengertian konsumen dalam UUPK dan UUOJK tampaknya apa yang dimaksud dengan konsumen dalam kedua undangundang tersebut sangatlah berbeda. Menurut UUPK yang dimaksud dengan konsumen adalah konsumen akhir, yakni pemakai barang dan/atau jasa dan tidak untuk diperdagangkan, sedangkan menurut UUOJK yang dimaksud dengan konsumen adalah pihak yang menempatkan dananya atau memanfaatkan pelayanan jasa lembaga sektor jasa keuangan, tanpa melihat motivasi pihak yang menempatkan dan/ atau memanfaatkan jasa di lembaga jasa keuntungan untuk mencari keuntungan atau tidak (pelaku usaha). Kondisi demikian tentunya sangat berbeda dengan pengertian konsumen yang dimaksud dalam UUPK, mengingat bahwa UUPK tidak melindungi konsumen pihak ketiga misalnya investor, karena konsumen demikian bukanlah konsumen sebagaimana dimaksud dalam UUPK, karena motif konsumen ini adalah untuk mencari keuntungan. ${ }^{15}$

Jika melihat pada pengertian konsumen dalam UUPK dan UUOJK seharusnya UUOJK tersebut merupakan konsumen yang lebih khusus yakni konsumen di bidang jasa, yakni di sektor jasa keuangan. Logikanya bahwa konsumen di sektor jasa keuangan tersebut seharusnya juga tercakup dalam pengertian konsumen dalam UUPK yakni sebagai konsumen di bidang jasa, sehingga seharusnya UUOJK dapat dipandang sebagai lex specialis dari UUPK.

Jika UUPK dipandang sebagai lex generalis dari UUOJK, maka seharusnya ketentuan-ketentuan dalam UUPK juga dapat diterapkan bagi semua konsumen di sektor jasa keuangan. Namun, ternyata ketentuan-ketentuan UUPK tidak dapat diterapkan

\footnotetext{
${ }^{15}$ Yusuf Shofie, Penyelesaian Sengketa Konsumen menurut Undang-Undang Perlindungan Konsumen (UUPK), Citra Aditya Bakti, Bandung, 2003, h. 15.
} 
bagi semua konsumen di sektor jasa keuangan. Hal ini terjadi karena adanya perbedaan definisi konsumen dalam kedua undang-undang tersebut. UUOJK mendefinisikan konsumen di sektor jasa keuangan tidak dalam pengertian sebagai konsumen akhir saja, tetapi juga sebagai pelaku usaha yang motifnya adalah untuk mencari keuntungan.

Pembedaan pengertian konsumen dalam UUOJK dengan UUPK ini dapat dipahami karena jika UUOJK mendefinisikan konsumen di sektor jasa keuangan sebagai konsumen akhir saja, maka akan ada pihakpihak yang menempatkan dana atau memanfaatkan pelayanan lembaga jasa keuangan yang tidak tercakup sebagai konsumen di sektor jasa keuangan, misalnya pemodal di pasar modal. Akibatnya bahwa konsumen pemodal di pasar modal tersebut tidak dapat terlindungi oleh UUOJK. Sehingga konsekuensi maka pengertian konsumen di sektor jasa keuangan dalam UUOJK ada yang dapat disebut sebagai konsumen akhir sebagaimana dimaksud dalam UUPK misalnya konsumen perbankan, pembiayaan dan asuransi, tetapi ada juga konsumen di sektor jasa keuangan yang berkedudukan bukan sebagai konsumen akhir menurut UUPK, yakni pemodal di pasar modal. Sehingga dalam UUOJK menggunakan definisi konsumen bukan hanya konsumen akhir saja, tetapi definisi konsumen dalam UUOJK diberikan definisi yang luas yakni konsumen adalah pihak-pihak yang menempatkan dananya dan/atau memanfaatkan pelayanan yang tersedia di lembaga jasa keuangan.

Berdasarkan uraian di atas, bahwa walaupun dalam UUOJK mengatur perlindungan konsumen, khususnya perlindungan konsumen di sektor jasa keuangan, tetapi UUPK secara umum tidak dapat dikatakan sebagai lex generalis dari UUOJK. Hal ini dikarenakan jika UUPK merupakan lex generalis dari UUOJK maka seharusnya ketentuan-ketentuan dalam UUPK dapat diterapkan bagi semua konsumen di sektor jasa keuangan. Namun kenyataannya tidaklah demikian, karena adanya perbedaan pengertian konsumen dalam UUPK dan UUOJK. Tidak semua konsumen di sektor jasa keuangan dapat disebut sebagai konsumen sebagaimana yang dimaksud dalam UUPK. UUPK telah membatasi perlindungan hukum yang diberikan kepada konsumen yakni terhadap konsumen akhir. Namun demikian, UUOJK juga dapat dipandang sebagai lex specialis dari UUPK sepanjang berkaitan dengan konsumen di sektor jasa keuangan yang merupakan konsumen akhir sebagaimana dimaksud dalam pengertian konsumen menurut UUPK. Hal ini mengingat bahwa tidak bisa dinafikan begitu saja keberadaan konsumen akhir sebagai salah satu konsumen di sektor jasa keuangan.

Pengaturan perlindungan konsumen di sektor jasa keuangan seharusnya memperhatikan keberadaan peraturan perundang-undangan perlindungan konsumen di Indonesia. UUPK sebagai undangundang payung atau umbrella act bagi pengaturan di bidang perlindungan konsumen di Indonesia seharusnya menjadi rujukan terhadap pembentukan peraturan perundang-undangan yang berkaitan dengan perlindungan konsumen. Upaya-upaya mewujudkan perlindungan hukum terhadap konsumen sebaiknya dilaksanakan dalam kerangka sistem hukum ${ }^{16}$ perlindungan konsumen, sehingga tidak terkesan parsial serta memperlihatkan ego sektoral kelembagaan. Hal ini dapat dilihat dalam konsiderans UUOJK, di mana sama sekali tidak mengacu atau mengkaitkan dengan UUPK. Walaupun terdapat perbedaan pengertian konsumen dalam UUPK dan UUOJK, seharusnya UUOJK juga dikaitkan dengan UUPK, mengingat dalam pengertian konsumen di sektor jasa keuangan juga terdapat konsumen akhir sebagaimana dimaksud dalam UUPK.

\section{Perlindungan Hukum terhadap Konsumen Jasa Keuangan Pasca Pemberlakuan UUOJK Dikaitkan dengan UUPK}

Pemberlakuan UUOJK membawa harapan dan kepastian hukum terhadap perlindungan konsumen khususnya konsumen di sektor jasa keuangan. Hal ini mengingat bahwa UUOJK telah mengatur secara khusus mengenai perlindungan konsumen di sektor jasa keuangan. Selain itu, UUOJK juga mengamanatkan pembentukan lembaga OJK, yang memiliki kewenangan melakukan pengaturan, pengawasan, pemeriksaan, dan penyidikan kegiatan di sektor jasa keuangan. Adapun kewenangan yang dimiliki oleh OJK meliputi di sektor Perbankan, Pasar Modal, Perasuransian, Dana Pensiun, Lembaga Pembiayaan, dan Lembaga Jasa Keuangan Lainnya.

Tujuan pembentukan OJK antara lain adalah untuk melindungi kepentingan masyarakat dan konsumen di sektor jasa keuangan. Adapun perlindungan konsumen di sektor jasa keuangan adalah perlindungan terhadap konsumen dengan

${ }^{16}$ Sudikno Mertokusumo, Penemuan Hukum: Sebuah Pengantar, Liberty, Yogyakarta, 2009, h. 18. 
cakupan perilaku pelaku usaha jasa keuangan. ${ }^{17}$ Pasal 1 angka (1) UUPK menegaskan bahwa perlindungan konsumen adalah segala upaya menjamin adanya kepastian hukum untuk memberikan perlindungan konsumen. Perlindungan hukum terhadap konsumen pada dasarnya adalah pemenuhuhan atas hak-hak konsumen yang seharusnya diberikan kepada konsumen, yang sesungguhnya identik dengan perlindungan yang diberikan hukum terhadap hakhak konsumen. ${ }^{18}$

Perlindungan hukum terhadap konsumen yang dilakukan oleh OJK berupa tindakan pencegahan kerugian konsumen, pelayanan pengaduan sampai dengan pembelaan hukum terhadap konsumen di sektor jasa keuangan. Tindakan pencegahan kerugian konsumen dilaksanakan dengan memberikan informasi dan edukasi terkait dengan karakteristik sektor jasa keuangan. Selain itu OJK dapat meminta lembaga jasa keuangan untuk menghentikan kegiatannya apabila berpotensi merugikan konsumen atau masyarakat. Pelayanan pengaduan konsumen dilaksanakan dengan menyiapkan perangkat pengaduan dan mekanisme pengaduan konsumen yang dirugikan oleh pelaku usaha di sektor jasa keuangan. Selanjutnya OJK juga dapat melakukan pembelaan hukum berupa memerintahkan tindakan tertentu kepada lembaga jasa keuangan untuk menyelesaikan pengaduan konsumen, serta dapat mengajukan gugatan gugatan kepada pelaku usaha atau pihak lain yang merugikan konsumen.

Perlindungan hukum terhadap konsumen di sektor jasa keuangan yang dilakukan oleh OJK terdiri dari tindakan pencegahan dan pasca terjadinya kerugian konsumen. Dalam melaksanakan tugasnya, OJK diberikan kewenangan untuk melakukan pengaturan, pengawasan hingga penindakan terhadap pelaku usaha di sektor jasa keuangan. Jika dikaitkan UUPK, fungsi dan kewenangan tersebut tidak pernah diatur atau dimiliki oleh lembaga/badan yang ada dalam UUPK, yakni Badan Perlindungan Konsumen Nasional (BPKN), Lembaga Perlindungan Konsumen Nasional (LPKN) dan Badan Penyelesaian Sengketa Konsumen (BPSK).

BPKN mempunyai fungsi memberikan saran dan pertimbangan dalam upaya perlindungan konsumen kepada pemerintah. BPKN tidak mempunyai

\footnotetext{
${ }^{17}$ Pasal 1 angka (3) POJK Perlindungan Konsumen.

18 Shidarta, Hukum Perlindungan Konsumen Indonesia, Grasindo, Jakarta, 2004, h. 19.
}

kewenangan dalam hal penindakan terhadap pelaku usaha seperti yang dimiliki oleh OJK. Selain memberikan saran dan masukan kepada pemerintah, fungsi BPKN lainnya lebih diarahkan kepada pencegahan, pengembangan terhadap perlindungan konsumen melalui penelitian, penyebarluasan informasi perlindungan konsumen, mendorong berkembangnya lembaga perlindungan konsumen, serta menerima pengaduan tentang perlindungan konsumen. Dalam hal adanya pengaduan mengenai perlindungan konsumen, BPKN bukanlah lembaga yang memiliki kewenangan untuk menyelesaikan pengaduan konsumen. Pengaduan yang disampaikan kepada BPKN akan menjadi bahan kajian sebagai pertimbangan kepada pemerintah. Adapun terhadap pengaduan konsumen yang terdapat unsur sengketa konsumen, BPKN akan merekomendasikan penyelesaiannya baik melalui BPSK maupun melalui pengadilan.

OJK dalam rangka perlindungan konsumen di sektor jasa keuangan telah menerbitkan POJK Perlindungan Konsumen dan POJK LAPS. POJK Perlindungan Konsumen dan POJK LAPS mengatur bahwa penyelesaian sengketa konsumen di sektor jasa keuangan pada tahap pertama melalui mekanisme pelayanan dan pengaduan konsumen yang disediakan oleh pelaku usaha di sektor jasa keuangan. Dalam hal tidak mencapai kesepakatan penyelesaian pengaduan, konsumen dapat melakukan penyelesaian sengketa di luar pengadilan atau melalui pengadilan. Penyelesaian sengketa di luar pengadilan dilakukan melalui LAPS. Selanjutnya dalam hal penyelesaian sengketa tidak dilakukan melalui LAPS, konsumen dapat menyampaikan permohonan kepada OJK untuk memfasilitasi penyelesaian pengaduan Konsumen yang dirugikan oleh pelaku di Pelaku Usaha Jasa Keuangan.

Sebelum pemberlakuan POJK Perlindungan Konsumen dan POJK LAPS, UUPK menentukan bahwa penyelesaian sengketa konsumen dapat diselesaikan melalui pengadilan maupun di luar pengadilan. Penyelesaian sengketa konsumen di luar pengadilan dilaksanakan oleh BPSK. BPSK merupakan badan dalam UUPK yang secara khusus dibentuk untuk menyelesaikan sengketa antara konsumen dengan pelaku usaha. Penyelesaian sengketa di BPSK dilaksanakan melalui BPSK, dengan cara konsiliasi, mediasi dan arbitrase. 
BPSK dibentuk dan berada pada setiap Kabupatan/Kota di seluruh Indonesia. Hal ini untuk mempermudah konsumen untuk menyelesaikan sengketa antara konsumen dengan pelaku usaha, karena UUPK telah menentukan bahwa pengajuan gugatan kepada pelaku usaha diajukan melalui BPSK di tempat kedudukan konsumen atau BPSK terdekat jika di tempat kedudukan belum terbentuk BPSK. Hal ini merupakan salah satu hal baru yang diatur dalam UUPK dalam hak pengajuan gugatan yakni gugatan diajukan di tempat penggugat, bukan di tempat tergugat. Hal ini berbeda dengan keberadaan LAPS dalam POJK LAPS yang tidak diwajibkan berada di setiap daerah, yakni berkedudukan di Jakarta. Saat ini telah terbentuk 6 LAPS yang kesemuanya berkedudukan di Ibu Kota Negara Jakarta, yakni: pertama, Badan Mediasi dan Arbitrase Asuransi Indonesia (BMAI) untuk sektor Perasuransian; kedua, Badan Arbitrase Pasar Modal Indonesia (BAPMI) untuk sektor Pasar Modal; ketiga, Badan Mediasi Dana Pensiun (BMDP) untuk sektor Dana Pensiun; keempat, Lembaga Alternatif Penyelesaian Sengketa Perbankan Indonesia (LAPSPI) untuk sektor Perbankan; kelima, Badan Arbitrase dan Mediasi Perusahaan Penjaminan Indonesia (BAMPPI) untuk sektor Penjaminan; keenam, Badan Mediasi Pembiayaan dan Pergadaian Indonesia (BMPPI) untuk sektor Pembiayaan dan Pegadaian. ${ }^{19}$

Keberadaan BPSK di satu sisi yang berada di setiap Kabupaten/Kota akan dapat mempermudah konsumen dalam menuntut hak-haknya melalui BPSK, dibandingkan harus menyelesaikan melalui LAPS sektor jasa keuangan yang berada di Jakarta. Hal ini dapat menimbulkan kesulitan bagi konsumen di sektor jasa keuangan yang berada di daerah atau di luar Ibu Kota Jakarta untuk untuk menuntut hak-hak mereka sebagai konsumen, karena harus mengeluarkan biaya ekstra untuk ke Jakata. Namun di sisi lain permasalahan hukum terkait di sektor jasa keuangan juga memiliki karakteristik sektor jasa keuangan, layanan dan produknya, yang juga membutuhkan Sumber Daya Manusia (SDM) yang memahami permasalahan di sektor jasa keuangan. Sehingga penanganan sengketa konsumen di sektor jasa keuangan seharusnya juga mendapatkan penanganan yang khusus pula.

\footnotetext{
${ }^{19}$ http://www.ojk.go.id/id/kanal/edukasi-dan-perlindungankonsumen/Pages/Lembaga-Alternatif-Penyelesaian-Sengketa. aspx, diakses tanggal 22 Desember 2015.
}

Pemberlakuan UUPK dan UUOJK yang samasama mengatur mengenai perlindungan terhadap konsumen, diharapkan dapat semakin melindungi konsumen. Namun, dalam implementasinya menimbulkan ketidakjelasan terkait adanya perbedaan definisi konsumen yang terdapat dalam UUPK maupun OOJK. Dalam prakteknya tidak semua konsumen yang diatur dalam UUOJK bukanlah merupakan konsumen diatur dalam UUPK, yakni sebagai konsumen akhir. Permasalahan yang muncul dalam hal pengajuan gugatan konsumen melalui BPSK. Pengajuan gugatan konsumen melalui BPSK hanya dapat dilakukan oleh konsumen dalam pengertian konsumen dalam UUPK yakni sebagai konsumen akhir. Sedangkan pengertian konsumen dalam UUOJK dapat meliputi pelaku usaha/pihakpihak yang menempatkan atau memanfaatkan pelayanan yang tersedia di lembaga jasa keuangan.

Perbedaan definisi konsumen dalam UUPK dan UUOJK menyebabkan adanya perlakuan yang berbeda dalam hal perlindungan hukum terhadap konsumen di sektor jasa keuangan. Konsumen di sektor jasa keuangan yang merupakan konsumen akhir sebagaimana dimaksud dalam UUPK dapat menggunakan perangkat hukum dalam UUPK dan UUOJK beserta POJK. Sedangkan bagi konsumen di sektor jasa keuangan yang bukan merupakan konsumen akhir hanya dapat menggunakan perangkat hukum dalam UUOJK dan POJK.

Bagi konsumen di sektor jasa keuangan yang merupakan konsumen akhir, maka perlindungan hukumnya konsumen dapat memilih apakah akan menggunakan UUPK atau UUOJK. Dalam hal tuntutan pemenuhan hak-haknya konsumen dapat memilih penyelesaian sengketa konsumen di luar pengadilan yang dilaksakan oleh BPSK ataukah melalui LAPS yang dibentuk oleh asosiasi pelaku usaha yang bersangkutan.

Dalam hal penyelesaian sengketa konsumen, UUPK telah mengamanatkan pembentukan BPSK di setiap Kabupaten/Kota. Dalam menuntut haknya kepada pelaku usaha, UUPK telah menentukan bahwa gugatan kepada pelaku usaha dilaksanakan di tempat kedudukan konsumen. Hal ini akan sangat memudahkan kepada konsumen daripada jika harus mengacu pada asas umum pengajuan gugatan dimana gugatan di tempat kedudukan tergugat. Berbeda halnya jika konsumen akan menyelesaikan sengketa konsumen melalui Lembaga Alternatif Penyelesaian 
Sengketa Konsumen yang berada di Jakarta. Dari segi hukum acara, penyelesaian sengketa konsumen berdasarkan UUPK juga telah memberikan kemudahan-kemudahan bagi konsumen, yakni dengan adanya beban pembuktian terbalik (unsur kesalahan), sehingga dalam hal ini pelaku usahalah yang diberikan kewajiban untuk membuktikan adanya tidaknya kesalahan pada diri pelaku usaha. Selain itu, putusan BPSK juga bersifat final dan mengikat walaupun di dalam praktiknya masih terdapat problematika dari eksekusi putusan BPSK, yakni adanya upaya keberatan kepada pengadilan negeri ${ }^{20}$ dan putusan BPSK yang tidak mempunyai kekuatan eksekutorial karena tidak memiliki irah-irah Demi Keadilan Berdasarkan Ketuhanan Yang Maha Esa, ${ }^{21}$ tetapi dari segi hukum acaranya keberadaan BPSK telah memberikan kemudahan-kemudahan kepada konsumen.

Penyelesaian sengketa konsumen bagi konsumen di sektor jasa keuangan dalam hal ini konsumen akhir, pada dasarnya konsumen dapat memilih apakah akan menyelesaikan sengketa konsumen baik di pengadilan maupun melalui di luar pengadilan. Baik UUPK dan POJK Lembaga Alternatif Penyelesaian Sengketa di Sektor Jasa Keuangan memberikan kesempatan bagi para pihak untuk penyelesaian sengketa konsumen baik melalui pengadilan maupun melalui di luar pengadilan dimana sifatnya merupakan pilihan para pihak. Namun jika tidak tercapai kesepakatan, maka berdasarkan UUPK maka pilihan sukarela para pihak ini merupakan pilihan dari konsumen. Hal ini mengingat bahwa penunjukkan BPSK sebagai lembaga penyelesaian sengketa konsumen ditunjuk secara langsung berdasarkan UUPK, sedangkan penyelesaian sengketa konsumen melalui Lembaga Alternatif Penyelesaian Sengketa Konsumen di Sektor Jasa Keuangan hanya didasarkan pada Peraturan OJK, dan tidak diperintahkan langsung oleh UUOJK. Asas hukumnya bahwa jika terjadi konflik antara dua peraturan perundang-undangan yang tidak berkedudukan sama, mengatur materi

\footnotetext{
${ }^{20}$ Yussy Adelina Mannas, "Upaya Keberatan atas Putusan Badan Penyelesaian Sengketa Konsumen Ditinjau dari Hukum Acara dan Undang-Undang Perlindungan Konsumen", Jurnal Hukum Acara Perdata ADHAPER, Vol. 1 No. 1, Januari-Juni 2015, h. 93.

${ }^{21}$ Hanun Rahmaniar Helmi, "Eksistensi Badan Penyelesaian Sengketa Konsumen dalam Memutus Sengketa Konsumen di Indonesia", Jurnal Hukum Acara Perdata ADHAPER, Vol. 1 No. 1, Januari-Juni 2015, h. 79.
}

yang sama tetapi bertentangan satu sama lainya maka berlakulah asas lex superior derogat legi inferiori. ${ }^{22}$

Penggunaan dua perangkat hukum UUPK dan UUOJK ini bagi konsumen di sektor jasa keuangan dalam hal ini merupakan pilihan dari konsumen. Konsumen dapat memilih ketentuan hukum mana lebih dapat melindunginya untuk memperjuangkan hak-haknya sebagai konsumen. Bagi konsumen di sektor jasa keuangan yang bukan merupakan konsumen akhir, maka konsumen di sektor jasa keuangan hanya dalam menggunakan perangkat hukum UUOJK dan POJK Perlindungan Konsumen dan POJK LAPS saja. Konsumen dalam hal ini harus mengoptimalkan peran OJK dalam memfasilitasi perlindungan konsumen dengan beberapa aturan yang telah diterbitkannya, yakni POJK Perlindungan Konsumen dan POJK LAPS.

Perlindungan hukum konsumen di sektor jasa keuangan dapat dibedakan jadi dua, yakni perlindungan hukum terhadap konsumen di sektor jasa keuangan yang merupakan konsumen akhir dan konsumen di sektor jasa keuangan yang bukan sebagai konsumen akhir. Bagi konsumen di sektor jasa keuangan yang berkedudukan sebagai konsumen akhir dapat dilindungi oleh UUPK dan/atau UUOJK beserta POJK. Sedangkan bagi konsumen di sektor jasa keuangan yang bukan merupakan konsumen akhir maka hanya mendapatkan perlindungan dari UUOJK beserta POJK.

Pembentukan UUOJK serta keberadaan OJK merupakan hal yang baru dalam rangka perlindungan konsumen di sektor jasa keuangan. OJK memiliki peranan yang sangat sentral dalam hal pengaturan dan pengawasan terhadap pelaku usaha di sektor jasa keuangan. Hal ini dapat melengkapi kekurangan yang belum diatur dalam UUPK khususnya perlindungan hukum terhadap konsumen di sektor jasa keuangan. Sehingga dalam hal ini antara UUOJK dan UUPK dapat saling melengkapi satu sama lain, sehingga dapat lebih memberikan perlindungan kepada konsumen di sektor jasa keuangan.

\section{PENUTUP}

\section{Kesimpulan}

Pertama, Pengaturan perlindungan konsumen di sektor jasa keuangan dalam UUOJK pada dasarnya merupakan peraturan khusus yang mengatur mengenai

${ }^{22}$ Sudikno Mertokusumo, Teori Hukum, Cahaya Atma Pustaka, Yogyakarta, 2012, h. 55. 
perlindungan konsumen di sektor jasa keuangan. Namun karena adanya perbedaan definisi konsumen dalam UUPK dan UUOJK maka secara umum UUPK bukan merupakan lex generalis dari UUOJK. UUOJK dapat dipandang sebagai lex specialis dari UUPK sepanjang mengenai konsumen dalam pengertian konsumen menurut UUPK. Hal ini mengingat bahwa tidak semua ketentuan dalam UUPK dapat diterapkan bagi semua konsumen di sektor jasa keuangan, karena UUPK hanya melindungi konsumen dalam pengertian sebagai konsumen akhir.

Kedua, Perlindungan hukum terhadap konsumen jasa keuangaan pasca pemberlakuan UUOJK dapat mengacu pada UUPK dan/atau UUOJK. Bagi konsumen di sektor jasa keuangan yang merupakan konsumen akhir sebagaimana dimaksud dalam UUPK, maka konsumen mendapatkan perlindungan dari UUPK dan UUOJK beserta POJK. Sedangkan bagi konsumen di sektor jasa keuangan yang bukan merupakan konsumen akhir, maka konsumen di sektor jasa keuangan tersebut hanya mendapatkan perlindungan dari UUOJK dan POJK.

\section{Rekomendasi}

Pertama, Bagi pihak-pihak terkait yakni OJK, Direktorat Perlindungan Konsumen Kementerian Perdagangan, dan Badan Perlindungan Konsumen Nasional (BPKN) sebaiknya melakukan sinkronisasi dan harmonisasi terkait dengan pengaturan perlindungan konsumen di sektor jasa keuangan, agar tercipta kepastian hukum bagi konsumen dan para pihak yang berkepentingan.

Kedua, Bagi konsumen di sektor jasa keuangan yang merupakan konsumen akhir sebagaimana dimaksud dalam UUPK, dalam menuntut hakhaknya sebaiknya menggunakan perangkat hukum UUPK maupun peraturan khusus dalam UUOJK dan POJK. Hal ini mengingat bahwa UUPK telah memberikan kemudahan-kemudahan bagi konsumen dalam menuntut haknya. Selanjutnya konsumen juga dapat menggunakan ketentuan-ketentuan khusus yang terdapat dalam UUOJK, maupun ketentuan dalam POJK.

\section{DAFTAR PUSTAKA}

\section{Peraturan Perundang-Undangan:}

Undang-Undang Nomor 8 Tahun 1999 tentang Perlindungan Konsumen.
Undang-Undang Nomor 21 Tahun 2011 tentang Otoritas Jasa Keuangan.

Peraturan Otoritas Jasa Keuangan No. 1/ POJK.07/2013 tentang Perlindungan Konsumen Sektor Jasa Keuangan.

Peraturan Otoritas Jasa Keuangan No. 1/ POJK.07/2014 tentang Lembaga Alternatif Penyelesaian Sengketa di Sektor Jasa Keuangan.

Kepmen Deperindag No. 350/MPP/Kep/12/2001 tentang Pelaksanaan Tugas dan Wewenang Badan Penyelesaian Sengketa Konsumen.

\section{Buku:}

Mertokusumo, Sudikno, 2009, Penemuan Hukum: Sebuah Pengantar, Yogyakarta: Liberty. 2012, Teori Hukum, Yogyakarta: Cahaya Atma Pustaka.

Miru, Ahmadi \& Sutarman Yado, 2007, Hukum Perlindungan Konsumen, Jakarta: RajaGrafindo Persada.

Shidarta, 2004, Hukum Perlindungan Konsumen Indonesia, Jakarta: Grasindo.

Shofie, Yusuf, 2003, Penyelesaian Sengketa Konsumen menurut Undang-Undang Perlindungan Konsumen (UUPK), Bandung: Citra Aditya Bakti.

Soekanto, Soejono \& Sri Mamudji, 2006, Penelitian Hukum Normatif: Suatu Tinjauan Singkat, Jakarta: Rajawali Pers.

Sutedi, Adrian, 2014, Aspek Hukum Otoritas Jasa Keuangan, Jakarta: Raih Asa Sukses.

\section{Jurnal:}

Fibrianti, Nurul, "Perlindungan Konsumen dalam Penyelesaian Sengketa Konsumen melalui Jalur Litigasi”, Jurnal Hukum Acara Perdata ADHAPER, Vol. 1 No. 1, Januari-Juni 2015.

Helmi, Hanun Rahmaniar, "Eksistensi Badan Penyelesaian Sengketa Konsumen dalam Memutus Sengketa Konsumen di Indonesia", Jurnal Hukum Acara Perdata ADHAPER, Vol. 1 No. 1, Januari-Juni 2015.

Mannas, Yussy Adelina, "Upaya Keberatan atas Putusan Badan Penyelesaian Sengketa Konsumen ditinjau dari Hukum Acara dan Undang-Undang Perlindungan Konsumen", Jurnal Hukum Acara Perdata ADHAPER, Vol. 1 No. 1, Januari-Juni 2015. 
Satory, Agus , "Perjanjian Baku dan Perlindungan

Konsumen dalam Transaksi Bisnis Sektor Jasa Keuangan: Penerapan dan Implementasinya di Indonesia", Padjadjaran Jurnal Ilmu Hukum, Vol. 2 No. 2, Agustus 2015.
Internet:

http://www.ojk.go.id/id/kanal/edukasi-danperlindungan-konsumen/Pages/LembagaAlternatif-Penyelesaian-Sengketa.aspx., diakses tanggal 22 Desember 2015. 